\title{
The methodology of machinery and equipment maintenance adopted by the textile industries located in the Zona da Mata Mineira
}

\author{
La metodología de maquinaria y equipo de mantenimiento adoptada \\ por las industrias textiles ubicadas en la Zona da Mata Mineira
Lisleandra Machado ${ }^{1,2 *} \quad$ Manoel Gonçales Filho $^{1} \quad$ Nilton Cesar Carrazo $^{1}$
Ana Carolina Melega Duarte de Oliveira ${ }^{1} \quad$ Lívia Meneguite Ávila $^{2}$
Neuzete Pires Ferreira ${ }^{2} \quad$ Fernando Celso de Campos ${ }^{1}$

Received: February 20, 2015, Accepted: June 2, 2016

Recibido 20 de febrero de 2015 aceptado 2 de junio de 2016

\begin{abstract}
The objective of this research is to demonstrate the methodology adopted by the maintenance textile industries, which are located in the Zona da Mata Mineira region, in Minas Gerais Brazil. The research emphasized the general nature of the maintenance management of these companies. The survey applied was presented through graphs with appropriate descriptions and comments for easy viewing of the results. The survey was conducted in a universe of 54 companies in the textile industry / manufacturing /garments in Zona da Mata Mineira region between September and November 2014. This article is linked to a research project funded by FAPEMIG with same name, still in progress.
\end{abstract}

Keywords: Textile industry, machinery and equipment maintenance of, Zona da Mata Mineira.

\section{RESUMEN}

El objetivo de este trabajo es demostrar la metodología de mantenimiento adoptada por las industrias textiles que se encuentran ubicadas en la región de la Zona da Mata Mineira, en el estado de Minas Gerais, Brasil. La investigación puso de relieve la naturaleza general de la gestión de mantenimiento de estas empresas. La encuesta aplicada fue presentada por medio de gráficos con descripciones y comentarios para facilitar la visualización adecuada de los resultados. La encuesta fue realizada en un universo de 54 empresas en la industria textil/confección de ropa en la región de la Zona da Mata Mineira entre los meses de septiembre a noviembre del año 2014. Este artículo está vinculado a un proyecto de investigación del mismo nombre financiado por FAPEMIG, todavía en curso.

Palabras clave: Industria textil, mantenimiento de maquinaria y equipo, Zona da Mata de Minas Gerais.

1 Universidade Metodista de Piracicaba. Campus Santa Bárbara d'Oeste. Rod. Luis Ometto Km 24 (SP 306). Santa Bárbara d'Oeste, SP, Brasil. CEP: 13451-900. E-mail: lisleandra.machado@ifsudestemg.edu.br; manoelgincalesfilho@gmail.com; nilton.carraro@fgv.br; acmelega@unimep.br; fccampos@unimep.br

2 Instituto Federal de Educação Ciência e Tecnologia do Sudeste de Minas Gerais. Campus Santos Dumont. Rua Técnico Panamá, 45 - Bairro Quarto Depósito. Santos Dumont, MG, Brasil. CEP: 36240-000.

E-mail: livia.avila@ifsudestemg.edu.br; neuzete.ferreira@ifsudeste.edu.br

* Corresponding author 


\section{INTRODUCTION}

The production sector associated with the textile industry is considered one of the oldest in the world since it is dedicated to satisfying human beings' needs, in other words, to dress people. The textile sector is of utmost importance to the world's historical financial development because it triggered the Industrial Revolution in the $19^{\text {th }}$ century when the steam engine began to being used to operate the English loom. In current economy, the textile industry contributes to evolution and stands out due to its capacity for high investment and reduction of laborforce.

The global textile market has been reporting constant growth in the volume produced in the global textile market, wich has been experiencing constant growth in what is referred to as volumes produced for international trade [1].

Global production of textile articles, measured by industrial consumption of fibers and filaments, grew at an average annual rate of $4.2 \%$ in the past 10 years while the world's population grew at an average rate of $2 \%$ per year, which represents an important per capita growth in the world consumption of textile products in this period.

World textile production including threads, filaments, fabric, knits, line of household articles, specialties and confections, went from approximately 80 million tons in 2012 with calculations based on the total consumption of fibers and filaments of that year. The production of clothing articles, estimated at 48 million tons was included in this volume [1].

In 2013, there were 89.1 million tons of textile fiber that were consumed worldwide, representing an increase of $6.1 \%$ over the total amount in 2012. However, in the period between 2000 and 2013, there was a $50 \%$ increase or the equivalent to an average growth of $3.1 \%$ per year.

Keeping in mind that a large part of the population still has low spending power and that half still lives rurally, the possibility of greater future growth is high. As the population's income increases with better distribution, as the population migrates to cities, heavily due to economic growth in non-developed countries, there will surely be significant growth in world textile consumption.
Brazil ranks fourth among the world's largest producers of clothing and is fifth among the largest textile manufacturers [1].

The main region for textile production is the Southeast because it concentrates the largest consumer markets and hosts the main wholesale and retail distribution centers in the country. Nevertheless, the Southeast lost the market to the Northeast, Midwest and South regions of Brazil from the year 2009 to 2013.

In 2013, Brazilian textile production went from 11.1 kilograms per inhabitant with internal filament consumption of yearly thread production [1]. During this year, consumption reached 13.7 kilograms per inhabitant. This difference in consumption per inhabitant indicates that part of the internal consumption was surpassed by imports.

From 2000 to 2013, the average per capita income of Brazilians grew $42.9 \%$, while the population growth was $14.2 \%$ and a $1.6 \%$ production decrease with consumption per inhabitant being $21.8 \%$ greater.

Thus, in order for the textile sector to undergo continuous improvement with high levels of productivity, costs should be cut and compatible with production and expense goals in each company's global plan of action. All in all, the various textile industry sectors collaboratively need investments in corrective, preventative and predictive machine and equipment maintenance, and the most modern do proactive maintenance work.

This research was structured in the following manner: After the introduction, in part two, there is information about the Zona da Mata Mineira mesoregion, then it talks about the Brazilian clothing and textile industry and afterwards, the literature review about corrective and preventative maintenance. In the fifth section, results, discussions and approaches are shown graphically and afterwards it ends with the conclusions.

\section{THE DA ZONA DA MATA MINEIRA MESOREGION}

Zona da Mata de Minas Gerais is a region that stands out on the historical and socioeconomic senses of the State [2]. The Region was home to $18^{\text {th }}$ century gold mining, and then with the decline of the gold cycle, 
specialized in agriculture and livestock throughout the $19^{\text {th }}$ century. In the $20^{\text {th }}$ century, agribusiness experienced a decline, thus causing socio-economic stagnation in several activities.

With a population of $2,173,374$ inhabitants, it is considered the third most populous region of the state, representing $11 \%$ of the mining inhabitants.

The Zona da Mata, polarized by the city of Juiz de Fora, see Figure 1, is well located in the state of Minas Gerais and Brazil, has an infrastructure in relatively good condition, favoring market access. The region, crossed by major federal and state highways (BR-040, BR-262, BR-267, BR-116 and BR-393), and railways (Atlantic Center and Steel Railway) is close to major cities like Belo Horizonte, Rio de
Janeiro and São Paulo, thus making it sensitive to changes in socio-economic development. It also has two important federal universities, Federal University of Juiz de Fora (UFJF), Federal University of Viçosa (UFV) and IFSUDESTEMG - Federal Institute of Education Science and Technology of southeast Minas Gerais [2]. In 2000, Juiz de Fora's influence expanded, occupying parts of the areas of Cataguases and Muria, probably because of the activities related to the textile industry with a tendency of the coverage to converge on Rio de Janeiro's surroundings.

The city, Juiz de Fora, at the end of the $19^{\text {th }}$ century and beginning of the $20^{\text {th }}$ century, was the largest urban industrial center in the state of Minas Gerais and one of the most prosperous

\section{ZONA DA MATA MESOREGION}

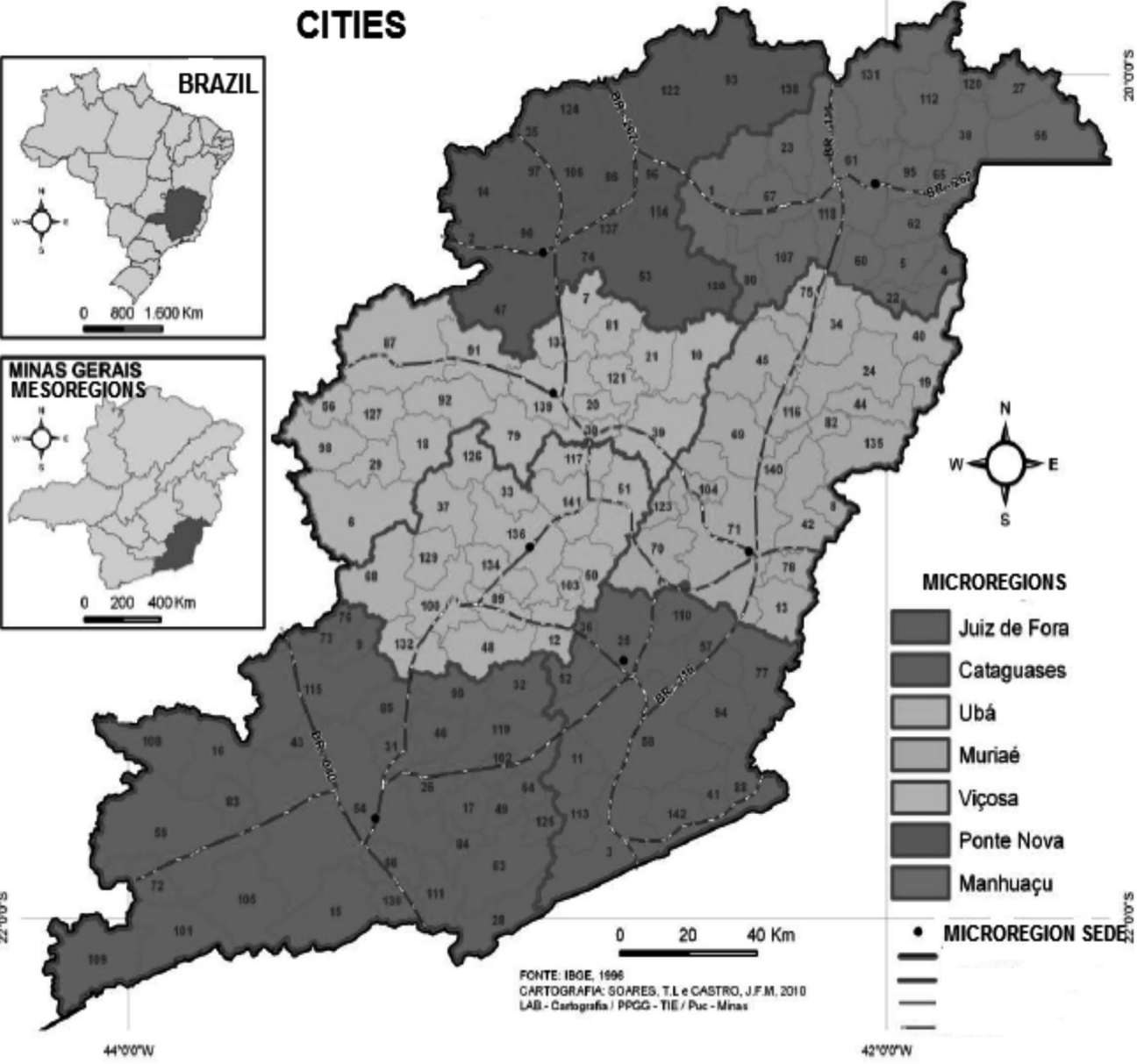

Figure 1. Zona da Mata location map of mesoregions and microregions of the state of Minas Gerais. 
cities in the country [3]. Since its production was concentrated in traditional industrial sectors, notably textile, it was called "Manchester Mineira" in reference to the important English industrial center. It is worthy mentioning that industry in Juiz de Fora had a strong concentration in the textile industry. In 1908, spinning and weaving concentrated $61.92 \%$ of the labor and $59.30 \%$ of the invested local capital [4]. The implementation of the textile industry is also due to climatic conditions because the high humidity in the city air creates better conditions for working with cotton thread. However, the data which reflects the textile/clothing sectors in Juiz de Fora APL and the surrounding region refers to 2005 and 2008 , in other words, outdated. This data describes that the textile and clothing sector stand out in the industrial organization of Juiz de For a. According to the 2008's survey [5], one of the barriers in development of the textile sector is the difficulty of contracting skilled labor. What hinders production from weaving to production is the difficulty of finding professionals to take the posts. At the time the survey, data shows that the greatest difficulty is hiring seamstresses. The index is $22.3 \%$. Another professional which also appeared in the survey were repairmen for machinery and equipment maintenance and were second in the ranking of most difficult in hiring with an indicator of $10.1 \%$, followed by professionals in the field of design, designers and development creation with rates of $9.2 \%$ and $8.4 \%$, respectively.

\section{TEXTILE INDUSTRY AND BRAZILIAN CLOTHING}

The history of the domestic industry owes much to the textile and clothing sectors. Its scale, density and complexity portray the strength of its socioeconomic structure [6].

It is this structure that serves as the basis for its further internationalization and the emergence of new entrepreneurs.

The competitive environment of textile companies and Brazilian manufacturing is expanding, a singular local effect of what had been occurring in all sectors and throughout the world as a result of the globalization process. This expansion gradually introduces new organizational species that are more diverse and better adapted to the conditions of the new economic order.

Competing for the most demanding markets enables companies to offer better products. Facing challenging situations raises the level of business intelligence, unfolds and multiplies operations and creations and finally involves other productive activities, which culminate in the generation more and better jobs.

In Figure 2, is the network structure that represents the relationship between the main activities developed in the industry $[2-3,7]$.

\section{CORRECTIVE AND PREVENTATIVE MAINTENANCE}

The textile industry's production sector evolved according to the evolution of pre-existing manufacturing techniques and the discovery of new techniques. In the early days, looms were extremely simple and manually operated. Currently,

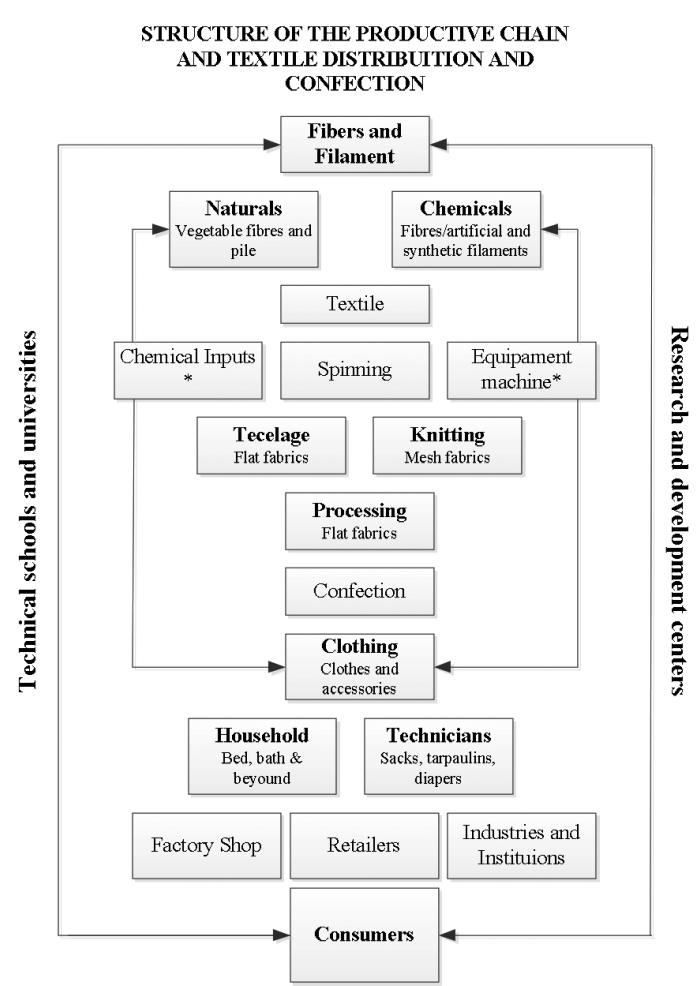

Figure 2. Relations among the main actors in the sector. 
automated machines make fabric coming from natural and synthetic fibers.

Then, the textile sector's biggest problem occurred, which is machine and equipment maintenance this because each one of these show completely different constructive characteristics than others. It is known that the fundamental objectives of maintenance are: (i) guaranteeing the quality of products made by the machines and (ii) extending their working life. These two objectives can be achieved if the maintenance improves the machine and equipment capacity used in the production.

Thus, this review describes the two methods that have appeared in the responses of the applied survey which were corrective and preventative maintenance.

The task performed after the occurrence of a failure and intended to replace an item in a state where it can perform properly its required, this is called corrective maintenance [3]. Corrective maintenance is effective: (i) No preventative maintenance is effective; (ii) The cost of failure is lower that preventative maintenance to avoid failure; (iii) the failure is of low importance.

Corrective maintenance is one that performs urgent interventions when there is unforeseen machine stoppage due to breaking or a defect in the material it produces. [8] The maintenance mechanic or staff e staff goes to the machine to check the situation and determines what should be done in accordance with available resources: spare parts and personnel.

And to corroborate [9], it is said that it is sometimes better to let the machine stop or break than stop it for preventative maintenance. This procedure, apparently erroneous, is justified by the simple reason that taking a machine off production incurs the manufacturing costs. In short, corrective maintenance should continue to exist.

Under aspects of preventive maintenance, preventive maintenance requires careful planning, in which all machine data is recorded and controlled [10]. According to the data, there are programmed stoppages for intervention by maintenance personnel.

About preventative maintenance, during its execution, machine parts that are broken due to wear are replaced. Lubricants are also changed. And it is worth noting that many mechanical components of textile machinery should be lubricated daily [11].

In this respect, there is no defect that can not be repaired, provided the mechanic and/or electrician receive specialized training to work with textile machinery. Being qualified and having experience, the person in charge of maintenance will be proactive and solve textile machinery problems with precision, getting them ready for performing their functions; maximum production and quality.

\section{MATERIALS AND METHODS}

The absence of information regarding maintenance methods adopted by textile companies of the Zona da Mata Mineira is a reality. Therefore, it was decided to do a search amongst clothing companies in order to get familiarized with the maintenance of small and medium-sized companies in the textile industry and when possible, check if the maintenance environment of these companies has similar characteristics to other textile companies.

This research reveals the general characteristics of maintaining these companies, exposed by describing the answers to the questions, comments and, where appropriate, descriptive presentation to facilitate the understanding of the results.

From September to November 2014, 54 questionnaires were applied to assess the maintenance methodology adopted by the textile industries in the Zona da Mata Mineira region. For assessment purposes, the research was based on the articles [12] and [13] which emphasize issues assigned following a maintenance process.

The research consisted of a field interview with companies registered in the Clothing Industry Unions of Juiz de Fora [5] and Santos Dumont, which had a total of 54 formal enterprises. It should be noted that the research tool used is after the references. The questionnaire the research instrument consisted of 20 open questions.

In a descriptive - quantitative nature, this work was developed through data collection, questionnaire application and surveys (poll) currently used in several knowledge areas - economy, politics, environment, marketing, social sciences, health; 
and in this case, gathering information on the maintenance of machinery and equipment for the textile sector of the Zona da Mata Mineira region in compliance with scientific methodological protocol. Research Survey can be described as obtaining data or information regarding characteristics, actions or opinions of a certain group of people appointed as representative of the target population through a survey instrument, usually a questionnaire [14].

\section{RESULTS AND DISCUSSIONS}

This sub-item shows the main discussions about some questions that the author considered most important and that are part of the questionnaire applied on companies in the clothing sector from the Zona da Mata mineira region.

One of the questions was about the existence of a mission, concerning policies for maintenance, if some type of maintenance software is used and if it has been self-developed. The answer was that no mission for maintenance has been established in an organized way via bulletin boards or manuals and there is also no clear policy to be followed, nor any internal procedures described. Thus, the mechanics and electricians took a stance that maintenance is something related to their direct actions such as carrying out assignments or even thouse related to their corrective and/or preventative maintenance. A very important aspect is that there is the use of specific software for maintenance management, even though there is free software called SIGMA that enables service requests via browser to be opened in the SIGMA system [15], following the progress of the request via browser in regards to (i) approval or dissatisfaction (including the reason) of the service request; (ii) the work carried out in the requirements; (iii) and the conclusion of the service order generated by the request. The existing software is called PPC - production planning and control interfaced with billing request.

Another interesting subject was what the biggest challenge of maintenance and use of the $5 \mathrm{~s}$ techniques is. The greatest challenge for maintenance was executing the service without rework due to the lack of training of maintenance professionals (this is a weakness of human resource management.). About the order, arrangement and cleaning in maintenance, no monitoring has been drawn up because there are moments when some maintenance tools can not be found on the tool board, (located in the warehouse). This is a weakness of logistics management.

The quantitative analysis of functional levels of the maintenance organization chart was a very important question given that there are two hierarchical levels, the maintenance coordinator and their assistant. The function of maintenance manager doesn't exist. However, on the maintenance team, these is one "genius" whose main characteristic is transforming scrapped machines into something productive to resell. The level of education required for hiring is a minimum of elementary school with a tendency point at vocational high school. However, the response obtained was that eventually professionals without the proper level of education, but who are specialists in certain types of equipment; practical experience is what is valued.

Other aspects analyzed were: The percentage of machines with a life longer than 2, 5, 10, 10, 15 years, if equipment modernization is usual, control cost of equipment life cycle. The answers: almost $50 \%$ of the machines are close to their 10th year of use which increases the cost of electricity consumption and even some possible damage to the machinery because there is an oscillation of the electricity consumed in the region during periods of heavy rain and between 06 to $10 \mathrm{am}$. Companies are investing in technology and innovation. They will acquire solar panels for water heating which will facilitate fabric washing. This procedure reduces cost of washing by $3 \%$, also the number of employees from fourteen to six in this process and also provides a reduction in the stock of raw material. They acquired ten machines from Canada. These machines make seamless panties and underwear, in other words, reduce payroll in relation to seamstresses. The question about cost control of the equipment lifestyle remains. There has been no answer.

Continuing the questions, the following question was posed: Who trains the equipment operators. About the training, it is done by SENAI CETIQT [16], and acts as the main Human Resources Training Center of the National Textile Chain and one of the most prominent in the world, with complete pilot plants that reproduce the manufacturing environment, in addition to making pilot plants, an integrated network of laboratories and an area of Innovation, Studies 
and Research, focusing on anthropometry, behavior and consumption, Color, Design, Creative Economy, Technological Forecasting and marketing, Socioenvironmental Sustainability and Responsibility.

Furthermore, also the system used to anticipate failures was asked. Systematic forecasting of failures with the use of methodologies is hardly used. In interviewed companies have machines stops the machines once a year for preventative maintenance; the other 364 days is corrective maintenance, or the "genius" manages the transformations resulting from machines acquired from other companies.

The response was unanimous for the following questions, NO. Here are the questions: The use of practices related to TPM (Total Productive Maintenance) and estimating when you want to adopt them. The use of practices related to the RCM (Reliability Centered Maintenance).

Productivity improvement programs implemented in maintenance. Percentage of expected results achieved by the use of improvement programs. If the company was certified by ISO 9000 standards and if it intends to do so.

Important to note again that this research consisted of interviews with companies in the Zona da Mata Mineira region and that there has been no comparison with textile companies from other regions.

\section{CONCLUSIONS}

The particularities of the textile industrial base and the Zona da Mata Mineira region of clothing justify the need and relevance of research that show its strategic economic significance of machinery and equipment maintenance, the processes and working conditions, and their implications for the development of the region.

Belief in the saying "prevention is better than cure" is not considered a constant for companies given the annual parade for preventative maintenance and taking care of old problems which is nothing but a justification for corrective maintenance. Preventative maintenance can often be used in the textile industry because it ensures constant engine operation and quality products. What was confirmed by [9], is that sometimes it is better to let the machine stop due to breakage rather than stop it for preventative maintenance. This procedure, apparently erroneous, is justified by the simple reason that shutting down a machine incurs in manufacturing costs. In short, corrective maintenance should continue to exist.

This research contributes through the research presented to what happens in the reality of textile industries in-the Zona da Mata region. They fall far short of scientific theories presented during the Industrial Maintenance Management class. However, it demonstrates that much work can be done since there are other methods to apply in the area that was the object of study. Another type of maintenance used in the textile industry is the prediction that is based on monitoring mechanical components in operation. In the textile industry, the presence of proactive maintenance is also a reality. This type of maintenance analyzes the causes of defects with the objective of developing systems and mechanisms where they no longer appear. Thus, the working life of the equipment increases and reduces the possibility of breakage with increased production. It is a perspective of future work.

A very important factor is the textile sector [17], which has been researched at the most important polos and industrial centers such as the region of Americana (SP) and Santa Catarina imposing the need for investigations in other regions such as Minas Gerais and its regional divisions such as the Zona da Mata region.

\section{ACKNOWLEDGEMENTS}

The authors thank CAPES and IF SUDESTE MG for research collaboration.

\section{REFERENCES}

[1] Iemi. "Relatório Setorial da Indústria Têxtil Brasileira". Brasil Têxtil. São Paulo, BR. Vol. 14 No 14, pp. 1-186. August, 2014.

[2] J.FM. Castro and T.L. Soares. "Análise das potencialidades socioeconômicas da zona da mata de Minas Gerais (1991-2000): uma proposta metodológica". Caderno de Geografia. Vol. 22 N 37 . 2012. ISSN: 0103-8427.

[3] S.S. Souza and C.R.C. Lima. "Manutenção centrada em confiabilidade como ferramenta 
estratégica”. XXIII Encontro Nac. de Eng. de Produção - Ouro Preto, Brazil. 21/24 october, 2003.

[4] S.Q.A. Bastos. "Reflexões sobre o desenvolvimento local: a partir da análise do processo de industrialização de Juiz de Fora (MG)". Dissertação de Mestrado em Economia Aplicada FEA/UFJF 006/2007. Juiz de Fora, Brazil. 2007.

[5] Sindvest. "Diagnóstico das Indústrias do setor têxtil e vestuário de Juiz de Fora". Belo Horizonte. FIEMG/IEL/SINDIVEST/ JF, pp. 104. 1- Indústria têxtil - Minas Gerais - Diagnóstico do setor. 2- Indústria do vestuário - Minas Gerais - Diagnóstico do setor. 2008.

[6] L. Machado. "Análise da logística reversa a luz da lei $\mathrm{N}^{\circ} 12.305$ de agosto de 2010 política nacional de resíduos sólidos aplicados a indústria têxtil e de confecção brasileira em prol da sustentabilidade". Ingeniería. Buenos Aires, Argentina. 2014.

[7] Associação Brasileira da Indústria Têxtil e de Confecção. "Site". Date of visit: 14 May, 2014. URL: http://www.abit.org.br

[8] B.Emami-Mehrgani and S. Nadeau, J.P. Kenne. "Lockout/tagout and operational risks in the production control of manufacturing systems with passive redundancy". International Journal of Production Economics. Vol. 132, Issue 2, pp. 165-173. August, 2011.

[9] Y. Wang, C. Deng, J. Wu, Y. Wang and Y. Xiong. "A corrective maintenance scheme for engineering equipment". Engineering Failure Analysis. Vol. 36, pp. 269-283. Janeiro, 2014.

[10] P. Dehghanian, M. Fotuhi-Firuzabad, F. Aminifar and B. Billinton. "A Comprehensive Scheme for reliability-Centered Maintenance in Power Distribution Systems-Part II:
Numerical Analysis". IEEE Transactions on Power Delivery. Vol. $28 \mathrm{~N}^{\circ}$ 2. April, 2013.

[11] L. Doyen and O. Gaudion. "Modeling and Assessment of Aging and Efficiency of Corrective and Planned Preventive Maintenance". Browse Journals \& Magazines. Reliability, IEEE Transaction. Vol. 60, Issue 4. October, 2011.

[12] E.J.A.A. Furtado and A.C. Bornia. "Os sistemas de manutenção das grandes empresas têxteis do Ceará". XXII Encontro Nacional de Engenharia de Produção. Curitiba, Brazil. 23/25 October, 2012.

[13] R.A. Moura. "Check sua manutenção". In: Jornal do IMAM - Manutenção. Instituto IMAM. Year $18 \mathrm{~N}^{\circ}$ 44. June, 1997. URL: http://www.abepro.org.br/ biblioteca/ ENEGEP2002_TR17_0698.pdf

[14] A. Pinsonneault and K.L. Kraemer. "Survey research in manegement information systems: an assessement". Journal of Management Information System. 1993.

[15] Sigma-Sistema de Manutenção . Web - Sistema de Solcitação de Serviço Web. Date of visit: 15 nov. 2014. URL: http://www.redeindustrial. com.br/site/pagina. aspx ?id=244.

[16] Senai Cetiqt - Centro de Tecnologia da Indústria Química e Têxtil. Date of visit: 15 nov. 2014. URL: http://www.portaldaindustria. com.br/senai/canal/senaicetiqt/

[17] M.R. Batistoni, L.B.D. Yacoub, P. Sirelli, J.F.R. Moraes, J.S. Machado and N. Marques. "Relações de trabalho na indústria de malharia de meias de Juiz de Fora/MG". XIX Seminario Latinoamericano de Escuelas de Trabajo Social. El Trabajo Social en la coyuntura latinoamericana: desafíos para su formación, articulación y acción profesional. Universidad Católica Santiago de Guayaquil. Guayaquil, Ecuador. 4-8 Oct. 2009. 


\section{ATTACHMENT I}

\section{Search Tool - Questionnaire}

\begin{tabular}{|c|c|}
\hline Question 01: & If maintenance has mission and whether it is formalized. \\
\hline Question 02: & If the maintenance standards are formalized. \\
\hline Question 03: & The biggest challenge of maintenance. \\
\hline Question 04: & What should be added to maintenance if there were additional funds $50 \%$ of the current. \\
\hline Question 06: & Number of functional levels of the organization chart maintenance. \\
\hline Question 07: & The percentage of machines with higher life $15,10,5$ and 2 years. \\
\hline Question 08: & If there is equipment modernization practice. \\
\hline Question 09: & If there is control the cost of the equipment life cycle. \\
\hline Question 10: & On the order, tidiness and cleaning maintenance. \\
\hline Question 11: & On whether use is made of some maintenance software and your development is proper. \\
\hline Question 12: & About maintenance methods: the predictive technique applied. \\
\hline Question 13: & The percentage of standardization of maintenance tasks. \\
\hline Question 14: & If there is standardization of tools cars, and who responds by tools. \\
\hline Question 15: & On who is the stock control maintenance parts. \\
\hline Question 16: & On the existence of decentralized staff. \\
\hline Question 17: & Who trains the operators of the equipment. \\
\hline Question 18: & The maintenance activities percentage suggested by manufacturer and followed by maintenance. \\
\hline Question 19: & If the company was certified by ISO 9000 standards and the company intends to make sure. \\
\hline Question 20: & The level of education required for admission. \\
\hline
\end{tabular}

